\title{
Impact of Rework on Building Project and Organisation Performance: A View of Construction Professionals in Nigeria
}

\author{
Eze Emmanuel Chidiebere ${ }^{1}$, Idiake John Ebhohimen ${ }^{2}$ \\ ${ }^{1}$ Quantity Surveying Department, Federal University of Technology Minna, Niger State, Nigeria. \\ *Corresponding E-mail: emmanueleze001@gmail.com
}

Received 7 August 2017; Revised 24 January 2018; Accepted 20 March 2018

DOI: https://10.30880/ijscet.2018.09.01.003

\begin{abstract}
Rework has become a menace in the construction industry as it leads to undesired and unnecessary loss of efforts. It degrades project cost, quality and schedule performance, and it occurs at both the design and construction phases of construction projects. This study therefore examined the perception of construction professionals on the impact of rework on the performance of both the project and the performing organisation. This was achieved by determining the most important effect of rework on project and organisational performance, and identifying variables in which the professionals view varies significantly. The study adopted a quantitative survey approach in which structured questionnaire was adopted as the research instrument. Mean item score was used in ranking the professionals perception of the effect of rework, and Kruskal-Wallis $\mathrm{H}$ test was used to identify the variables in which the professionals view varies. The study revealed that: rework has a very high impact of (MIS $=4.00)$ on project performance which results in projects over shooting their planned budget and planned duration, and degradation of project quality. Rework has a very high effect of (MIS = 4.04) on organisational performance leading to loss of profit/reduced profit, de-motivation of workers, and loss of future work/business. Disputes between contracted parties, design team dissatisfaction, de-motivation of workers and Fatigue are the factors in which the professionals' view varied significantly. It was recommended that there is the need for the training of construction stakeholders on construction rework and other variables that cause projects to over shoot their budget, time and other resource.
\end{abstract}

Keywords: Construction professionals, Organisational performance, Project performance, Rework, Nigeria

\subsection{Introduction}

The construction industry is the driving force behind socio-economic development of any nation [41]. Construction industry takes huge amount of money, time and energy [32]. It is among the major industries that contribute to economic growth and civilization; as such its importance is approved in all communities [32]. The activities of the industry improves the quality of life by providing infrastructures such as buildings, roads, hospital, schools among other facilities [40].

In spite of the significance of the construction industry, it is faced with the problems of poor financial performance, high cost of project delivery, poor quality and material waste and failure to deliver value to clients on schedule [2,40]. Consequently, the industry has been extensively criticized for poor performance and ineffective productivity [42]. The cost and schedule overruns often experienced in the construction projects delivery is directly and significantly attributable to rework factors [18]. [42] reaffirmed the fact that rework is one of the major factors responsible for the setback experienced in the industry.

Consequently, [28] affirmed that rework is a main contributor to time wastage and schedule overruns which ultimately impact on cost, resources and quality. According to [10], rework emerges as overtime, additional resources such as labour, plant, workers, and reductions in project scope and quality and schedule slippage. [25] opined that rework would naturally increase total project costs 
by $12.6 \%$. Similarly, [12] reported that rework can cause additional cost to construction of up to $12.4 \%$ of the total project cost. [26] reported that the indirect cost of rework is as high as six times the cost of rectifying failures.

Studies have revealed that the consequence of poor quality work such as rework are; denying clients value for their monies; dissatisfied customers; unsafe structures; contract disputes; battered reputation; resource wastage; loss of business; loss of profit/revenue; reduce market share; and increase time and cost of construction; extra charges, and increased professional fees [2, 6, 11, 15, $27,31,34,35,38,42,44,47]$.

[33] assessed rework cost of selected building projects in Ondo state, Nigeria. The study found out that there is a significant relationship between rework costs and each of the initial and final cost, cost overrun, and the initial time, final time and time overrun.

[43] evaluated the direct and indirect costs of rework in construction industry of South Africa. The study found out that total rework cost was $5.12 \%$ of the original contract value, and that rework contributes significantly to project cost overruns.

[29] analysed the cost and causes of rework in residential building projects in West Bank, Palestine. The study adopted questionnaire survey among 78 contractors. The study revealed that cost of rework in building projects ranges between 10\%-15\% of the original value. [4] studied the effect of rework on project performance in building project in Lagos State, Nigeria. The study adopted questionnaire survey with 52 construction professionals, and used descriptive and inferential analysis in its analysis. The study found out that rework impact on project cost and project schedule.

[3] carried out a study on projects management and the effect of rework on construction works. The study whose aim was to evaluate the relationship between projects management and the effect of rework on construction works, adopted a case study approach on two projects in Abuja metropolis, using inductive and qualitative method, and expository research design. The study found out that the combined effect of rework on the projects' time and cost were $54.70 \%$ and $28.55 \%$ respectively.

It is vital to know that these studies did not compare the responses of the professional regarding the effect of rework on project performance and organisation performance. It is based on this that this study assessed the relationship that exists among construction professionals regarding the effect of rework on construction project performance and on the performing organisations. The aim of this study is to examine the perception of construction professionals on the effect of rework on the performance of both the project and the performing organisation, with a view to ascertaining the level of rework impact. Constructions professionals do recognize that rework have considerably impact on project performance [28]. Rework is harmful to the performance and productivity of design and construction organisations; and it is a major contributor to cost and time overruns [25]. The specific objectives of this study were; to determine the most important effect of rework on project performance, to examine the most important effect of rework on organisational performance, and to identify variables in which the professionals view varies significantly. This study was guided by two hypotheses and they are; $\mathrm{H}_{1}$ : there is no significant difference in the perception of the different professions regarding the effect of rework on project performance, and $\mathrm{H}_{2}$ : there is no significant variation in the perception of the different professions regarding the effect of rework on organisation performance.

\subsection{Literature Review}

\subsection{Impact of rework on project performance}

Rework impacts project performance in areas such as cost, time, contractual claims and disputes, design team satisfaction, client satisfaction, contractor's satisfaction and quality [42]. [19] identified changes by owner, errors and omissions in design as the most recurring causes of costs overrun; and rework is a direct contributor to cost and time overruns. Clients' satisfaction means that the client is satisfied with the quality of the product or services and they meet or exceed his expectations; the 
client is not satisfied when the quality of a product or a service is under his expectations [22]. [39] proposed key indicators such as liquidity indicator, schedule variance indicator, work in progress reporting, and scorecard indicator; as a measure of the overall health of the contractor's firm. These indicators measure the satisfaction or dissatisfaction of the contractor; and the occurrence of rework will affect the satisfaction of the contractor because of either cost or time overruns [39].

Cost Overrun is a very regular incident and is associated with almost every type of projects within the construction industry [7]. Cost has been seen as the major factor for measuring project success. The major factors affecting project costs are qualitative; such factors are client priority on construction time, procurement methods, contractor's planning capability and market conditions including the activity level of construction [13]. Regrettably, a lot of construction projects incur cost overruns as a result of rework. Consultants work very hard to avoid it because its resultant high effect on project cost increases [25]. [30] found out that the mean of rework costs were 5.5\% of the value of the contract; comprising $2.75 \%$ direct costs, $1.75 \%$ and $1 \%$ indirect costs for major contractor and subcontractors respectively. This study was based in New South Wales, Australia. [32] reported that the cost of rework is $1.30 \%-3.30 \%$ of contract value, and an average of $2.095 \%$; and rework time of 3.0\%-8.0\% with an average of 5.182\%. [35] also reported a positive link between rework cost and project time overrun; indicating that increase in cost of remedying nonconforming work will give rise to increase project completion time.

Construction project time overrun is defined as an addition of time further than the agreed contractual time at the tender stage [15]. Rework can lead to a considerable addition of a project's time and cost overrun, especially during the construction stage. The effect of delays or time overruns for the contractor included increased costs, reduced profit margin and battered reputation [15]. Similarly, [14] reported that time overrun is a recurring decimal in the construction industry of Nigerian.

[21] estimated that the cost of non-conformance amounted to $7.1 \%$ of total construction work hours. It is believed that the direct effects of redoing and rectifying poor quality work on project management businesses according to [36] are; additional time for remedying failures and extension of supervision time among others. According to [8], completing projects within the budgeted time is an indication of an efficient construction industry; and the estimation of completion time of projects is dependent on the intuition, skill and experience of the planner/ planning engineer. [31] argued that, in the course of rectifying rework, parts of a structure must be discarded and new materials needed for reconstruction, there may be a quality compromise that can waste resources. Value for clients is a very complex and subjective problem; in construction, quality is recognized as a key element in measuring the value of the project to clients [42]. Quality is very crucial in construction projects, [9] suggested that any product should have some specific standard in any industry that provides customer satisfaction and value for money.

Rework causes strained relationships in projects. One major result of the ripple effects of rework is damaged reputation and goodwill [26]. Battered reputation is one of the impacts of project time overrun or delays for contractors [15].

\subsection{Effect of rework on organisational productivity and performance}

Rework affects productivity through its impact on the morale level, absenteeism, dilution of supervision, fatigue, conflict and communication. [28] posited that aside the effect of rework on cost and schedule; rework also has negative influence on intra and inter-organisational relations and the psychological wellbeing of individuals.

Dilution of supervision is one of the factors that can affect productivity. [28] suggested that rework leads to diversion of resources which in turn dilutes supervision in other parts of a project.[28] outlined the effects of such dilution as; the need for extra supervision, as some extra time from subcontractors to redo work and this may cause stacking; and compromise of safety. Organisational conflicts that may result from rework, are intergroup conflict, interpersonal conflict, intra-group conflict, and inter- organisational conflict; questions regarding the causes of rework may cause conflict between client and contractor. [25] therefore, suggested that interorganisational conflict is 
an indirect consequence of rework; should rework happened then conflict may arise between the client and the contractor.

According to [36], rework has both direct and indirect effects on the performance of construction projects. For poorly managed projects, the overall impacts of rework may be equal to or even exceed the estimated profit margin (or markup). Also, there are cases in which the ripple effects of rework will be carried forward on different aspects such as reputation, stress, motivation and relationships. [36] revealed that additional time to re-do task, additional costs for re-doing work, additional materials for rework and subsequent wastage handling, and additional labour for rework and related extensions of supervising manpower; were the direct effect of the impact of rework on project management transactions.

Reworks have grave effect on individuals, an organisation and a project's performance indirectly [26]. At the organisation level, the indirect impacts of rework according to [26] are loss of future work, reduced profit, inter-organisational conflict, diminished professional image and poor morale. Also, according to Love [26], the indirect effect of rework at the individual level are; demotivation, stress, absenteeism, fatigue and poor morale. In fact, prolonged work hours being subjected by an individual due to errors, omissions, changes, fatigue and stress may emerge; thereby increasing the likelihood of even further rework occurring [1,24]. Indirect rework effects at the project level include; work inactivity such as waiting time, idle time, travelling time and dissatisfaction of end-users [24].

Reworks also have physiological and psychological consequences on the worker. Increased stress experienced owing to the added financial burden, loss of profit, as well as having to re-do work again, can be demoralizing and de-motivating [26].

Table 1: Summary of project performance measurement variables affected by rework

\begin{tabular}{cll}
\hline S/No & Variables & Sources \\
\hline 1 & Cost overrun & {$[36,28,42,19]$} \\
2 & Quality degradation & {$[36,28,42,19]$} \\
3 & Time overrun (extension) & {$[36,28,42]$} \\
4 & Contractual claims & {$[36,42]$} \\
5 & Disputes between contracted parties & {$[26,42]$} \\
6 & Design team dissatisfaction & {$[42]$} \\
7 & End-user/client dissatisfaction & {$[26,19,22]$} \\
8 & Contractor dissatisfaction & {$[26]$} \\
\hline
\end{tabular}

Table 2: Summary of organisational performance measurement variables affected by rework

\begin{tabular}{cll}
\hline S/No & Variables & Sources \\
\hline & & \multicolumn{1}{c}{} \\
1 & Loss of profit/ Reduced profit & {$[26,36]$} \\
2 & Loss of future work/business & {$[26]$} \\
3 & Absenteeism of workers & {$[26,1,24]$} \\
4 & De-motivation of workers & {$[26,1,24,28]$} \\
5 & Poor morale of workers love & {$[26,1,24,28]$} \\
6 & Inter organisational conflict & {$[26]$} \\
7 & Fatigue $\quad[26,1,24,36,28]$
\end{tabular}




\subsection{Methodology}

Quantitative research approach was adopted for data collection, and well-structured questionnaires were used to collect data on the perception of the various professionals regarding the effect of rework on project and organisation performance. The questionnaire was self- administered, by the authors and through the help of trained field assistants who were properly briefed about the research topic and given the necessary information on how to administer the questionnaire.

The appropriateness of the questionnaire to meet the study objectives was carried out through a pilot survey. [16] opinined that research instrument (questionnaire) should be initially piloted in order to verify whether the questions are intelligible, unambiguous and easy to answer, as well as providing an opportunity to improve the questionnaire and determining the time required in completing the exercise. 16 of the draft questionnaire were randomly distributed to the selected construction professionals, and the final draft was adjusted based on their feedback.

The populations of the study are registered professionals such as: Builders, Quantity surveyors, Architects, and Engineers practicing within Abuja, Nigeria. The total population of this study is 6899 comprising (404 builders, 845 Quantity surveyors, 400 Architects and 5250 Engineers). In order to achieve a representative sample, a list of construction professional bodies in Abuja were obtained from the Abuja chapter secretariat of the various professional bodies namely Nigerian Institute of Building (NIOB) for builders, Nigerian Institute of Architects (NIA) for the architects, Nigerian Institute of Quantity Surveyors (NIQS) for quantity surveyors, and Nigerian Society of Engineer (NSE) for engineers. Abuja was selected for this study because it is the administrative headquarters of Nigeria; and it is one of the metropolitan cities in Nigeria with the highest population of Construction professionals practicing in either constructing or consulting firms within the built environment [40].

The sample size for this study is 364 , and this was derived applying the formula by [45, 23] to the population using a $95 \%$ confidence level.

$$
\mathrm{S}=\mathrm{X}^{2} \mathrm{NP}(\mathbf{1}-\mathbf{P}) \div \mathrm{d}^{2}(\mathbf{N}-\mathbf{1})+\mathbf{X}^{2} \mathbf{P}(\mathbf{1}-\mathbf{P}) \ldots \ldots \ldots \ldots \ldots \ldots \ldots \ldots \ldots \ldots \ldots \ldots \ldots \ldots
$$

\section{Where;}

$\mathrm{s}=$ sample size from finite population

$\mathrm{X}=$ based on confidence level 1.96 for $95 \%$ confidence was used for this study $\mathrm{d}$ $=$ Precision desired, expressed as a decimal (i.e. 0.05 for $5 \%$ used for this study $\mathrm{P}=$ Estimated variance in Population as a decimal (i.e. 0.5 for this study) $\mathbf{N}=$ total number of population

A total of 195 questionnaires were retrieved out of the 364 distributed. Out of the 195 response received, seven (7) were invalid because of incomplete response, and 188 were properly filled and was considered valid response, this represents a response rate of 51.64\%. The 188 valid responses consist of 32 builders, 61 quantity surveyor, 44 Architects, and 51 civil engineers. According to [5], this response rate is considered suitable for a study whose main focus is to gain responses from professionals and practitioners within the construction industry.

The questionnaire was based on a 5-point Likert scale and ranges from 1 to 5, with 5 being the highest. The analysis of the data collected were carried out using means item score, percentages, and Kruskal-Wallis $\mathrm{H}$ test. Tables and charts were also used to present the analyzed data. Mean item score was used to analyze and rank the variables of rework affecting project performance and the performing organisation. The cut off point for the determination of level of impact set for this study using mean item score with 5 being the highest point is written thus; $0.00<\mathrm{MS}<0.50$ : Little or no impact; $0.50<\mathrm{MS}<1.50$ : Low impact; $1.50<\mathrm{MS}<2.50$ : Moderate impact; $2.50<\mathrm{MS}<3.50$ : High impact; and 3.50< MS < 4.50: Very high impact.

Kruskal-Wallis $\mathrm{H}$ test was used to test the hypotheses in order to determine if there are statistically significant differences in the opinions of the respondents. Kruskal-Wallis test was also adopted to ascertain the variables in which the respondents view varies. The rule for accepting or rejecting the hypothesis is; 
i. $\quad$ accept hypothesis; if $P$-value $\geq 0.05$, and

ii. reject hypothesis; if $\mathrm{P}$-value $<0.05$.

These analyses were done using statistical package for social science (SPSS) Version 20

\subsection{Results and Discussions}

\subsection{General Information of Respondents}

Table 3 shows the analysis of the respondent's information. It is evident that $51.60 \%$ of the respondents work in contractors' organisation, and $20.74 \%$ and $25.0 \%$ work in the consultant and clients organisations respectively. Moreover, $48.40 \%$ of them have their years of experience range from 1-10 years, and 39.89\% have work in the construction industry for 11-20 years. This implies that they are experienced enough to give reliable information that will aid the study. In addition, $29.79 \%$ of the respondents have diploma degree, $46.28 \%$ have Bsc/Btech degree and $21.81 \%$ of them are master's degree holders. This implies that they are academically qualified to take active part in this study.

In addition, according to the respondents, $73.4 \%$ always keep records of rework incidents, $23.94 \%$ keeps record sometimes, and only $2.66 \%$ of them had never kept rework of rework incidences. Rework incidences cannot be completely attributable to a particular party, they respondents are of the opinion that the activities of contractors contribute most to rework with $37.77 \%$, and the consultant (31.38\%) and then the client/customer (18.09\%) closely follow this.

Also, the professional qualification of the respondents indicates that, $32.45 \%$ are quantity surveyors registered with the Nigerian Institute of Quantity Surveyors (NIQS), 17.02\% are builders registered with Nigerian Institute of Builders (NIOB), 23.40\% are Architects registered with Nigerian Institute of architects (NIA), and $27.13 \%$ are Engineers registered with the Nigerian Society of Engineers (NSE). The high proportion of quantity surveyors implies that they are involved in cost-associated matters such as rework in the construction industry. Similarly, the professional status of the respondents shows that, $21.81 \%$ of the respondents are probationer members of the various professional bodies, $76.06 \%$ are corporate members of the various professional bodies, and $2.13 \%$ are fellows of the professional bodies. The high proportion of the corporates members indicates that the respondents are professionally qualified to give an expert opinion on the subject of this study.

Table 3: Demographic Characteristics of Respondents

\begin{tabular}{lccc}
\hline Category & & Freq. & \% \\
\hline \multirow{2}{*}{ Organisational Type } & Classification & 39 & $20.74 \%$ \\
& Consultants & 47 & $25.00 \%$ \\
& Clients & 97 & $51.60 \%$ \\
Years of experience & Contractors & 5 & $2.66 \%$ \\
& Consultant/Contracting & $\mathbf{1 8 8}$ & $\mathbf{1 0 0 . 0 0 \%}$ \\
& TOTAL & 91 & $48.40 \%$ \\
& $1-10$ years & 75 & $39.89 \%$ \\
& $11-20$ years & 17 & $9.04 \%$
\end{tabular}




\begin{tabular}{|c|c|c|c|}
\hline & 41 years and above & 0 & $0.00 \%$ \\
\hline & TOTAL & 188 & $100.00 \%$ \\
\hline \multirow[t]{5}{*}{ Academic Qualification } & Diploma degree & 56 & $29.79 \%$ \\
\hline & Bsc/B.Tech & 87 & $46.28 \%$ \\
\hline & Master degree & 41 & $21.81 \%$ \\
\hline & Doctorate degree & 4 & $2.13 \%$ \\
\hline & TOTAL & 188 & $100.00 \%$ \\
\hline \multirow[t]{4}{*}{ Frequency of calculating/recording rework incidence } & Always & 138 & $73.40 \%$ \\
\hline & Sometimes & 45 & $23.94 \%$ \\
\hline & Never & 5 & $2.66 \%$ \\
\hline & TOTAL & 188 & $100.00 \%$ \\
\hline \multirow[t]{5}{*}{ Party's Activities that contribute most to rework } & Clients/owner & 34 & $18.09 \%$ \\
\hline & Consultant & 59 & $31.38 \%$ \\
\hline & Contractors & 71 & $37.77 \%$ \\
\hline & All stakeholders & 24 & $12.77 \%$ \\
\hline & TOTAL & 188 & $100.00 \%$ \\
\hline \multirow[t]{5}{*}{ Professional Qualification } & NIQS (Quantity Surveyors) & 61 & $32.45 \%$ \\
\hline & NIOB (Builders) & 32 & $17.02 \%$ \\
\hline & NIA (Architects) & 44 & $23.40 \%$ \\
\hline & NSE (Engineers) & 51 & $27.13 \%$ \\
\hline & TOTAL & 188 & $100.00 \%$ \\
\hline \multirow[t]{4}{*}{ Professional Status } & Probationer & 41 & $21.81 \%$ \\
\hline & Corporate & 143 & $76.06 \%$ \\
\hline & Fellow & 4 & $2.13 \%$ \\
\hline & TOTAL & 188 & $100.00 \%$ \\
\hline
\end{tabular}

\subsection{Effects of Rework on Project performance and organisational performance}

A normality test was first conducted on the collected data in order to ascertain the type of test to be carried out. The essence was to determine the nature of the data (parametric or nonparametric). To ascertain this, [37] and [17] suggested the use of Shapiro-Wilk normality test in studies with sample size of less than 2000. Result in Table 4 shows that the significant value of all the variables examined is 0.000 , which is less than the 0.05 required criteria for normality. Therefore, the collected data are non-parametric in nature and cannot be examined using normal parametric statistical techniques. This confirms the recommendation of [46] that Shapiro-Wilk test is the best choice for testing the normality of non-parametric data. Thus, Kruskal-Walis test; a nonparametric test, which is suitable when there is need to ascertain the significant difference in the perception of three or more categories of respondents, was employed in determining consistency in the opinion of the respondents within the four (4) different professions. 
Table 4: Normality Test result

\section{Shapiro-Wilk}

\begin{tabular}{|c|c|c|c|}
\hline Project Performance Variables & Statistic & $\mathrm{df}$ & P-value \\
\hline Cost overrun & 0.616 & 188 & 0.0000 \\
\hline Quality degradation & 0.749 & 188 & 0.0000 \\
\hline Time overrun (extension) & 0.715 & 188 & 0.0000 \\
\hline Contractual claims & 0.783 & 188 & 0.0000 \\
\hline Disputes between contracted parties & 0.83 & 188 & 0.0000 \\
\hline Design team dissatisfaction & 0.788 & 188 & 0.0000 \\
\hline End-user/client dissatisfaction & 0.825 & 188 & 0.0000 \\
\hline Contractor dissatisfaction & 0.837 & 188 & 0.0000 \\
\hline \multicolumn{4}{|c|}{ Shapiro-Wilk } \\
\hline Organisational performance Variables & Statistic & $\mathrm{df}$ & P-value \\
\hline Loss of profit/ Reduced profit & 0.696 & 188 & 0.0000 \\
\hline Loss of future work/business & 0.746 & 188 & 0.0000 \\
\hline Absenteeism of workers & 0.855 & 188 & 0.0000 \\
\hline De-motivation of workers & 0.746 & 188 & 0.0000 \\
\hline Poor morale of workers & 0.761 & 188 & 0.0000 \\
\hline Inter organisational conflict & 0.785 & 188 & 0.0000 \\
\hline Fatigue & 0.847 & 188 & 0.0000 \\
\hline
\end{tabular}

Table 5 shows the significant value derived from Kruskal-Wallis $\mathrm{H}$ test conducted on the variables for measuring project performance. Kruskal-Wallis $\mathrm{H}$ test was used to compare the views of construction professionals regarding the effect of rework on project performance. The result revealed that the p-values of 2 out of the 8 variables assessed were less than 0.05 . This implies that there is a significant difference in the way these respondents from the different professions in the construction industry view these 2 variables. These variables are Disputes between contracted parties, and Design team dissatisfaction. This difference is attributed to the individual perception of construction professionals as to the effect of rework on the project performance. However, it is observed that there is a significant relationship in the perception of the respondents on cost overrun, quality degradation, time overrun, contractual claims, enduser/client dissatisfaction, and contractor dissatisfaction.

Table 5: Comparism of Professionals Perception Regarding Effect of Rework on Project 
Performance

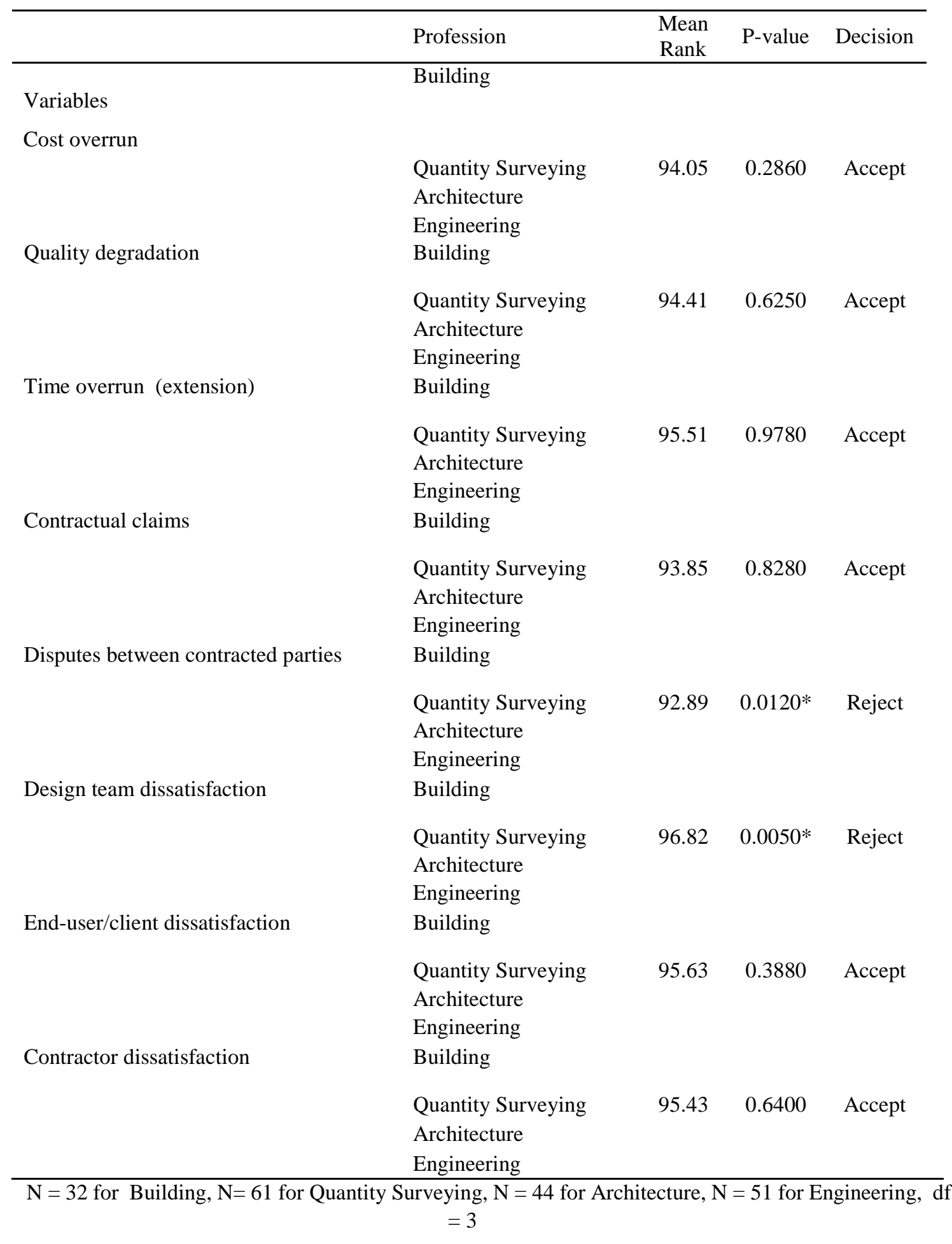

Table 6 shows the significant value derived from Kruskal-Wallis $\mathrm{H}$ test conducted on the variables for measuring organisational performance. The result revealed that the p-values of 2 out of the 7 variables assessed are less than 0.05 . This implies that there is a significant difference in the way the respondents from the different professions in the construction industry view these 2 variables. These variables are de-motivation of workers, and fatigue. This difference is attributed to the individual perception of construction professionals as to the effect of rework on the organisation. However, it is observed that there is a significant relationship in the perception of the respondents 
on Loss of profit/ reduced profit, Loss of future work/business, Absenteeism of workers, Poor morale of workers, and Inter organisational conflict.

Table 6: Comparism of Professionals Perception Regarding Effect of Rework on Organisation

Performance

\begin{tabular}{|c|c|c|c|c|}
\hline \multirow[b]{2}{*}{ Variables } & \multirow[b]{2}{*}{ Profession } & Mean & \multirow[b]{2}{*}{ P-value } & \multirow[b]{2}{*}{ Decision } \\
\hline & & Rank & & \\
\hline \multirow[t]{2}{*}{ Loss of profit/ Reduced profit } & Building & & & \\
\hline & $\begin{array}{l}\text { Quantity Surveying } \\
\text { Architecture } \\
\text { Engineering }\end{array}$ & 93.95 & 0.2270 & Accept \\
\hline \multirow[t]{2}{*}{ Loss of future work/business } & Building & & & \\
\hline & $\begin{array}{l}\text { Quantity Surveying } \\
\text { Architecture } \\
\text { Engineering }\end{array}$ & 93.95 & 0.5220 & Accept \\
\hline \multirow[t]{2}{*}{ Absenteeism of workers } & Building & & & \\
\hline & $\begin{array}{l}\text { Quantity Surveying } \\
\text { Architecture } \\
\text { Engineering }\end{array}$ & 94.18 & 0.5740 & Accept \\
\hline \multirow[t]{2}{*}{ De-motivation of workers } & Building & & & \\
\hline & $\begin{array}{l}\text { Quantity Surveying } \\
\text { Architecture } \\
\text { Engineering }\end{array}$ & 92.18 & $0.0000^{*}$ & Reject \\
\hline \multirow[t]{2}{*}{ Poor morale of workers } & Building & & & \\
\hline & $\begin{array}{l}\text { Quantity Surveying } \\
\text { Architecture } \\
\text { Engineering }\end{array}$ & 93.18 & 0.4020 & Accept \\
\hline \multirow[t]{2}{*}{ Inter organisational conflict } & Building & & & \\
\hline & $\begin{array}{l}\text { Quantity Surveying } \\
\text { Architecture } \\
\text { Engineering }\end{array}$ & 93.93 & 0.8330 & Accept \\
\hline \multirow[t]{2}{*}{ Fatigue } & Building & & & \\
\hline & $\begin{array}{l}\text { Quantity Surveying } \\
\text { Architecture } \\
\text { Engineering }\end{array}$ & 93.50 & $0.0360^{*}$ & Reject \\
\hline
\end{tabular}

\subsection{Effect of Rework on Project Performance}

Table 7 shows the result of the analysis of the respondents' response on the extent to which rework affect the overall performance of construction project with regard to the identified variables. Respondents were asked to rate the extent to which rework affect the variables of project performance measurement on a Likert scale of $1=$ not at all; $2=$ to least extent; $3=$ to some extent; $4=$ to a large extent and $5=$ to a very large extent. The most ranked effects by the builders are Cost 
overrun (MIS $=4.56$ ), Quality degradation (MIS $=4.31$ ) and Time overrun (MIS $=4.28)$, with an overall average of (MIS $=4.016$ ) which implies very high effect of $80.31 \%$ on the project. Quantity surveyors are of the opinion that the most rated effects of rework are Cost overrun (MIS $=4.61$ ), Time overrun (MIS $=4.41$ and Quality degradation (MIS $=4.08$ ), with an overall average of (MIS=3.939) which implies high effect of $78.77 \%$ on the project. The most ranked effects by the Architects are Quality degradation (MIS $=4.34$ ), Time overrun (MIS $=4.34$ ) and Cost overrun (MIS $=4.30)$, with an average of (MIS=4.17) which implies very high effect of $80.34 \%$ on the project. Similarly, the engineers are of the opinion that the most rated effects of rework are Cost overrun (MIS = 4.67), Time overrun ( MIS = 4.43) and Disputes between contracted parties (MIS = 4.24), with an overall average of (MIS=4.025) which implies very high effect of $80.49 \%$ on the project. Hence, on the overall, rework has most effect on Cost overrun (MIS $=4.53$ ), Time overrun (MIS = 4.37) and Quality degradation (MIS $=4.22$ ), with a mean average of 3.999, implying a high effect of $79.98 \%$ on project performance.

Table 7: Effect of Rework on Project Performance

\begin{tabular}{|c|c|c|c|c|c|c|c|c|c|c|}
\hline \multirow{2}{*}{ Factors } & \multicolumn{2}{|c|}{ Bldr. } & \multicolumn{2}{|c|}{ Q. S } & \multicolumn{2}{|c|}{ Arch. } & \multicolumn{2}{|c|}{ Engr. } & \multicolumn{2}{|c|}{ Overall } \\
\hline & $\overline{\mathrm{MIS}}$ & Rank & MIS & Rank & MIS & Rank & MIS & Rank & MIS & Rank \\
\hline Cost overrun & 4.56 & 1 & 4.61 & 1 & 4.30 & 3 & 4.67 & 1 & 4.53 & 1 \\
\hline Quality degradation & 4.31 & 2 & 4.08 & 3 & 4.34 & 1 & 4.16 & 4 & 4.22 & 3 \\
\hline Time overrun (extension) & 4.28 & 3 & 4.41 & 2 & 4.34 & 1 & 4.43 & 2 & 4.37 & 2 \\
\hline Contractual claims & 3.72 & 7 & 4.03 & 4 & 3.93 & 5 & 3.86 & 5 & 3.89 & 4 \\
\hline Disputes between contracted parties & 3.50 & 8 & 3.90 & 5 & 3.34 & 8 & 4.24 & 3 & 3.74 & 6 \\
\hline Design team dissatisfaction & 4.19 & 4 & 3.59 & 6 & 4.27 & 4 & 3.33 & 8 & 3.85 & 5 \\
\hline End-user/client dissatisfaction & 3.78 & 5 & 3.41 & 8 & 3.84 & 6 & 3.78 & 6 & 3.70 & 7 \\
\hline Contractor dissatisfaction & 3.78 & 5 & 3.48 & 7 & 3.77 & 7 & 3.73 & 7 & 3.69 & 8 \\
\hline Average & \multicolumn{2}{|c|}{$\begin{array}{c}4.016 \\
(80.31 \%)\end{array}$} & \multicolumn{2}{|c|}{$\begin{array}{c}3.939 \\
(78.77 \%)\end{array}$} & \multicolumn{2}{|c|}{$\begin{array}{c}4.017 \\
(80.34 \%)\end{array}$} & \multicolumn{2}{|c|}{$\begin{array}{c}4.025 \\
(80.49 \%)\end{array}$} & \multicolumn{2}{|c|}{$\begin{array}{c}3.999 \\
(79.98 \%)\end{array}$} \\
\hline
\end{tabular}

Bldr = Builder; QS = Quantity Surveyor; Arch. = Architect; Engr. Engineer

\subsection{Effect of Rework on Organisation Performance}

Table 8 shows the result of the analysis of the respondents' response on the extent to which rework affects the organisational performance. Respondents were asked to rate the extent to which rework affect the performance of the organisation carrying out the project on a Likert scale of $1=$ not at all; $2=$ to least extent; $3=$ to some extent; $4=$ to a large extent and $5=$ to a very large extent. According to the builders, the most effect of rework on the performing organisation are Loss of profit/ Reduced profit (MIS =4.28), Poor morale of workers (MIS = 3.97), and Loss of future work/business (MIS =3.88), with an average of (MIS =3.821) which implies a high effect of $76.43 \%$ on the organisation. Quantity surveyors are of the opinion that the most rated effects of rework on organisation are Loss of profit/ Reduced profit (MIS =4.56), Poor morale of workers (MIS = 4.34), and Loss of future work/business (MIS =4.30), with an average of (MIS = 4.096) which implies a very high effect of $81.92 \%$ on the organisation.

Also, the Architects are of the opinion that De-motivation of workers (MIS = 4.57), Loss of future work/business (MIS $=4.32$ ) and Loss of profit/ Reduced profit (MIS $=4.27$ ), with an average of (MIS=4.123) which implies very high effect of $82.47 \%$ on the organisation. Similarly, the engineers are of the opinion that the most rated effects of rework on the organisation are Loss of profit/ Reduced profit (MIS =4.24), Poor morale of workers (MIS = 4.10), and Loss of future work/business (MIS =4.12), with an average of (MIS = 4.112) which implies a very high effect of $82.24 \%$ on the organisation. Hence, on the overall, rework has most effect on the performance of an organisation in areas of are Loss of profit/ Reduced profit (MIS $=4.34$ ), de-motivation of workers 
(MIS = 4.28), and Loss of future work/business (MIS =415) with a mean average of 4.038, implying a very high effect of $80.76 \%$ on organisational performance.

Table 8: Effect of Rework on Organisational Performance

\begin{tabular}{lcccccccccc}
\hline \multirow{2}{*}{ Factors } & \multicolumn{3}{c}{ Bldr. } & \multicolumn{2}{c}{ Q. S } & \multicolumn{3}{c}{ Arch. } & \multicolumn{3}{c}{ Engr. } & \multicolumn{2}{c}{ Overall } \\
\cline { 2 - 11 } & MIS & Rank & MIS & Rank & MIS & Rank MIS & Rank MIS & Rank \\
\hline Loss of profit/ Reduced profit & 4.28 & 1 & 4.56 & 1 & 4.27 & 3 & 4.24 & 1 & 4.34 & 1 \\
De-motivation of workers & 3.69 & 5 & 4.23 & 4 & 4.57 & 1 & 4.63 & 5 & 4.28 & 2 \\
Inter organisational conflict & 3.84 & 4 & 4.03 & 5 & 3.86 & 6 & 3.92 & 4 & 3.92 & 5 \\
Poor morale of workers & 3.97 & 2 & 4.34 & 2 & 4.05 & 5 & 4.10 & 2 & 4.11 & 4 \\
Absenteeism of workers & 3.66 & 6 & 3.61 & 6 & 3.68 & 7 & 3.96 & 6 & 3.73 & 7 \\
Loss of future work/business & 3.88 & 3 & 4.30 & 3 & 4.32 & 2 & 4.12 & 3 & 4.15 & 3 \\
Fatigue & 3.44 & 7 & 3.61 & 6 & 4.11 & 4 & 3.82 & 7 & 3.75 & 6 \\
\hline \multicolumn{1}{c}{ Average } & 3.821 & 4.096 & & 4.123 & 4.112 & 4.038 \\
& $(76.43 \%)$ & $(81.92 \%)$ & $(82.47 \%)$ & $(82.24 \%)$ & $(80.76 \%)$ \\
\hline
\end{tabular}

Bldr = Builder; QS = Quantity Surveyor; Arch. = Architect; Engr. Engineer

\subsection{Discussion of result}

The study revealed that the professionals' perception varied significantly on disputes between contracted parties, and design team dissatisfaction. This difference may be connected to the different role performed by these professionals, and the depth of their understanding of rework. [42] observed that construction experts prefer to take a neutral position when it comes to the rework factors that impact on project performance. The study also revealed that the professionals' perception varied significantly on de-motivation of workers, and Fatigue. This difference may also be attributed to the different role performed by these professionals, and the depth of their understanding of rework. [42] observed that some construction experts do have feeling of disagreement on how rework can impact the performance of organisations, while other may prefer to take a neutral position.

Rework has an adverse effect on construction projects [42]. So, there is need to examine the problems rework cause to both the performance of projects and the performing organisations. This study revealed the most impacts rework has on construction projects, as perceived by construction professionals. For project performance, the top most effects are cost overrun, time overrun and quality degradation. Moreover, at the organisational level, the top most effects of rework are loss of profit/reduce profit, de-motivation of staff, loss of future work/business. This result corroborates the findings of [26] and [42]. [26] posited that reworks have grave effect on individual, an organisation and a project's performance indirectly. [26] posited that at the organisation level, the indirect impacts of rework are loss of future work, reduced profit, interorganisational conflict, diminished professional image and poor morale. Also, according to [26], the indirect effect of rework at the individual level are; de-motivation, stress, absenteeism, fatigue and poor morale. Indirect effects or rework at the project level include; work inactivity such as waiting time, idle time, travelling time and end-user dissatisfaction. Similarly, [42] found out that reduced profit, demotivation of workers, inter-organisational conflicts were highly ranked among the extent to which rework impacts on organisation's performance.

Regarding the effect of rework on project performance, [42] reported that cost overrun, time overrun and design team dissatisfaction dominates effect of rework on project performance. [36] revealed that additional time to rework, additional costs for covering rework occurrences, additional materials for rework and subsequent wastage handling, and additional labour for rework and related extensions of supervising manpower; were the direct effect of the impact of rework on project 
management transactions. [26] posited that reworks have both physiological and psychological consequences on the worker. Increased stress experienced due to the additional financial burden, loss of profit, as well as having to re-do work again, can be demoralizing and de-motivating [26]. Rework can negatively affect the performance and productivity of design and construction organisations $[8,25]$.

\subsection{Conclusion and Recommendations}

Rework has been established to be a major factor responsible for cost and time overruns of construction projects. It impact is not restricted to the project but also to the performing organisation. This study examined the perception of construction professionals regarding the effect of rework on project performance and organisation performance, through a questionnaire survey among construction professionals. Based on the findings, from the study, it was concluded that the professionals' perception varied significantly on 'disputes between contracted parties', 'design team dissatisfaction', 'de-motivation of workers' and 'Fatigue'. It was also concluded that rework has a high effect of $79.98 \%$ on project performance, with its impact occurring most in aspect such as cost overrun, time overrun and degradation of quality of the projects. Also, it rework has a very high effect of $80.76 \%$ on organisational performance leading to loss of profit/ Reduced profit, demotivation of workers, and Loss of future work/business.

Based on the findings and conclusion, the study therefore recommends the need for training of construction stakeholders on construction rework and other variables that cause projects to over shoot the budget, time and other resource. This training could be through workshops, seminars and conferences. These would increase the awareness of the stakeholders and as such, they will be better positioned physiologically and psychologically to deal with the consequences of rework. With this, no stakeholder should take a neutral stand and all hand s must be brought to bear in dealing with rework.

Early identification of rework by all stakeholders to minimise the effects of undiscovered design induced rework at the construction stages. Therefore, project participants should be alert, have a good foresight in identifying rework triggers, and eliminate them prior to commencement of work on site to avoid rework emergence. This will help project stakeholders put achievable mitigation plan in place to avoid the impact of rework emerging at any phase of the project. Also, the need for clarity, effectiveness and timeliness of instruction and information among project participants. In addition, the use of skilled and experienced professionals, skilled supervisors and proper implementation of quality management practices by both the design consultant and contractor throughout the project's phases, is necessary if rework free construction is to be achieved.

When these measures are implemented, the emergence of rework are put to check, and the cost, time and quality performance of construction projects would be improved. In addition, the performing organisation's profit will improve, workers will be better motivated and more business will be secured as there will be repeat patronage resulting from clients satisfaction.

Similar study should be carried out in the petroleum industry of Nigeria, and the SouthSouth region of Nigeria should be adopted as the study area because of the concentration of oil and gas companies within the region. There is need to ascertain if the effect of rework will be same in both the construction and petroleum industries. Also, a further study be undertaking to examine the perception of construction professionals regarding rework risks triggers and minimization measure within the construction industry of Nigeria. 


\section{References}

[1] Abdul-Hamid, T.K. and Madnick, S.E. (1991), Software project dynamics - an integrated approach, Prentice-Hall, Englewood Cliffs, NJ.

[2] Abdul-Rahman, I., Memon, A.H. \& Abd-Karim, A.T. 2013. Significant factors causing cost overruns in large construction projects in Malaysia. Journal of Applied Sciences, 13(2), pp. 286293. http:// dx.doi.org/10.3923/jas.2013.286.293

[3] Abeku, D. M., Ogunbode, E. B., Salihu,C., Maxwell, S. S. and Kure, M. A. (2016); Projects Management and the effect of Rework on Construction Works: A Case of selected Projects in Abuja Metropolis, Nigeria. International Journal of Finance and Management in Practice, Vol. 4, No. 1, June 2016.

[4] Ajayi, O. and Oyeyipo, O. (2015); effect of rework on project performance in bilding project in Nigeria. Internatioanl Journal of Engineering Research \& Technology (IJERT). Vol. 4 issue 02, February-2015.

[5] Alreck, P. L., \& Settle, R. B. (1985). "The survey research handbook." Richard D. Irwin, Inc., Homewood, Ill.

[6] Angelo, W. J. and Reina, P. (2002), Megaprojects Need More Study Up Front to Avoid Cost

Overruns. Retrieved December 29, 2016, from
http://flyvbjerg.plan.aau.dk/News\%20in\%20English/ENR\%20Costlies\%20150702.pdf

[7] Azhar, N., Farooqui,R. U., Ahmed S. M. (2008), Cost Overrun Factors In Construction Industry of Pakistan, First International Conference on Construction In Developing Countries (ICCIDC-I)

"Advancing and Integrating Construction Education, Research \& Practice" August 4-5, 2008, Karachi, Pakistan

[8] Chan D.W.M. and Kumaraswamy M.M. (1997), A comparative study of causes of time overruns in Hong Kong construction projects, International Journal of Project Management, 15 (1): 55-63.

[9] Chan, A. P. C. and Tam, C. M. (2000); "Factors affecting the quality of building projects in Hong Kong," international Journal of Quality \& Reliability Management, vol. 17, pp. 423-441.

[10] Cooper, K. G. (1993), the rework cycle: Benchmarking for the project manager, Project management Journal, 24 (1): 17-22.

[11] Dania, A.A., Kehinde, J.O. \& Bala, K. 2007. A study of construction material waste. In: Egbu, C.O. \& Tong, M.K.L (Eds). Proceedings of the 3rd Scottish Conference for Postgraduate Researchers of the Built \& Natural Environment (PRoBE) 20-22 November, Glasgow, United Kingdom. Glasgow: Glasgow Caledonian University, pp. 121-129

[12] Davis, K., Ledbetter, W.B. and Buratti, J.L. (1989), Measuring design and construction quality costs, ASCE Journal of Construction Engineering and Management, 115 (3): 389-400.

[13] Elchaig, T., Boussabinaine A., and Ballal T. (2005) "Critical determinants of construction tendering costs: Quantity surveyors’ standpoint”, International Journal of Project Management.

[14] Elinwa, AU, Joshua, M (2001). "Time overrun factors in Nigeria construction industry", Journal of Construction. Engineering Mgt., 127(5): 419-25.

[15] Endut, I. R. Akintoye, A. and Kelly J. (2005), Cost and time overruns of projects in Malaysia, Proceedings of the 2nd Scottish Conference for Postgraduate Researchers of the Built and Natural Environment (PRoBE) 16-17 November, Glasgow Caledonian University.

[16]Fellows, R. R. \& Liu, A. (2008). Research Methods for Construction, 3rd Edition. Wiley- Blackwell Science, London.

[17] Ghasemi, A. \& Zahediasl, S (2012). Normality Test for Statistical Analys is: A guide for nonstatisticians. International Journal of EndocrinolMetab, 10(2), 486-489

[18]Hwang, B. G., Thomas, S. R., Haas, C. T., and Caldas, C. H. (2009), Measuring the Impact of Rework on Construction Cost Performance, Journal of Construction Engineering and Management, 135 (3): 187-198

[19]Hwang, B., (2009), "Identifying Key Sources Affecting Construction Cost Performance", RICS COBRA Research Conference, University of Cape Town, 10-11th September2009, pp 138-149

[20] Josephson, P. E. and Hammarlund, Y. (1999). The causes and costs of defects in construction: A study of seven building projects. Automation in Construction, 8(6), pp. 681-687. 
[21] Josephson, P., Larsson, B. and H. Li. (2002). Illustrative benchmarking rework and rework costs in Swedish construction industry. Journal of Management Engineering, vol 18, issue 2, pp. 76-83

[22] Karna, S. (2009), "Concepts and Attributes of Customer Satisfaction on Construction” Dissertation PhD. Helsinki University of Technology, Department Structural Engineering and Building Technology.

[23] Krejcie, R.V. and Morgan, D.W. (1970). Determining Sample Size for Research Activities. Educational and Psychological Measurement, 30, Pp 607-610.

[24] Love P., Mandal P., Smith J., and Georgiou J., (2000), "DECOEM: A Design and Construction Rework Minimization Model", 1st International Conference on Systems Thinking in Management.

[25] Love, P. E. D. (2002a), Influence of project type and procurement Method of Rework Costs in Building Construction Projects, Journal of Construction Engineering and Management, 128 (1): 129.

[26] Love, P. E. D. (2002b), Auditing the indirect consequences of rework in construction: a case based approach, Managerial Auditing Journal, 17 (3): 138-146

[27] Love, P. E. D., Mandal, P. and Li, H. (1999a), determining the causal structure of rework in construction projects, Construction Management and Economics, 17 (4): 505-517.

[28]Love, P., \& Edwards, D. (2004a), "Determinants of Rework in Building Construction Projects ", Engineering, Construction and Architectural Management, 11(4), pp.259 -274.

[29] Mahamid, I. (2016). Analysis of Rework in Residential Building Projects in Palestine. Jordan Journal of Civil Engineering, Volume 10, No. 2.pp 197-208.

[30] Marosszeky, M. (2006). Performance Measurement and Visual Feedback for Process Improvement, A Special Invited Lecture presented in the SMILE-SMC 3rd Dissemination Workshop on 11th February 2006, Centre for Infrastructure and Construction Industry Development of The University of Hong Kong, Hong Kong.

[31] Mastenbroek,Y.C. (2010). Reducing rework costs in construction projects. Published Bsc thesis, University of Twente, San Pedro Sula, Honduras

[32] Meshksar, S. (2012); Cost And Time Impacts Of Reworks In Building A Reinforced Concrete Structure. Master Thesis. North Cyprus, Gazimagusa: Eastern Mediterranean University

[33] Oke , A. E. and Ugoje, O. F. (2013) "Assessment of rework cost of selected building projects in Nigeria", International Journal of Quality \& Reliability Management, Vol. 30 Issue: 7, pp.799-810, doi: 10.1108/IJQRM-Jul-2011-0103

[34] Okpala, D.C. and Aniekwu, A.N. (1988), Cause of high cost of construction in Nigeria .Journal of Construction Engineering and Management, ASCE , 114 (2) 223-34.

[35] Oyewobi, L. O., Ibironke, O. T, Ganiyu, B. O. and Ola-Awo, A. W. (2011a): Evaluating rework cost- A study of selected building projects in Niger State, Nigeria. Journal of Geography and Regional Planning Vol. 4(3), pp. 147-151, March 2011

[36] Palaneeswaran, E. (2006)." Reducing Rework to enhance Project Performance Levels", Proceedings of the one day Seminar on "Recent Developments in Project Management in Hong Kong."

[37] Pallant, J. (2005). SPSS Survival Manual: A Step By Step Guide to Data Analysis Using SPSS for Windows (Version 12). 2nd Edition, Allen \& Unwin, Crows Nest NSW 2065 Australia

[38] Rhodes, B. and Smallwood, J. J. (2003), Defects and rework in South Africa construction projects, Proceedings of the first CIBD post graduate conference, Port Elizabeth, South Africa, 12-14 October, 228-236.

[39] Rober, K. and Mclin, M. (2005), “Key Performance Indicators Drive Best Practices for General Contractors" FMI, Management consulting, Investment Banking for the Construction Industry, Microsoft Corporation

[40] Saidu, I. and Shakantu, W. M. (2016c). The contributions of Material Waste to project-cost Overrun in Abuja, Nigeria. Acta Structilia, 23 (1), 99-113

[41] Saidu, I. and Shakantu, W.M.W., (2016a). A Study of the Relationship between Material W aste and Cost Overruns in the Construction Industry. The 9th CIDB Postgraduate Conference Cape Town, South Africa. Emerging trends in construction organisational practices and projectmanagement knowledge area. Edited Windapo, A.O., 124-134, Feb, 2-4, 2016.

[42] Simpeh, E. K (2012). An Analysis of the Causes and Impact of Rework in Construction Projects. A Thesis submitted Cape Peninsula University of Technology, South Africa. 
[43] Simpeh, E.K., Ndihokubwayo, R., Love, P. E.D. (2012), Evaluating the direct and indirect costs of rework. Selected Works, Cape Peninsula University of Technology.ICEC2012-72.

[44] Tam, V.W.Y. 2008. On the effectiveness in implementing a waste-management-plan method in construction. Waste Management, 28(6), pp. 1072-1080. http://dx.doi.org/10.1016/j.wasman.2007.04.007

[45] The NEA Research Bulletin (1960). Small-Sample Techniques. Vol. 38, p. 99.

[46] Thode, H.J. (2002). Testing for normality. New York: Marcel Dekker; 2002

[47] Wasfy, M.A.F (2010). Severity and Impact of Rework, a Case Study of a Residential Commercial Tower Project in the Eastern Province-KSA. Master Thesis. Dhahran, Saudi Arabia: King Fahd University of Petroleum \& Minerals 